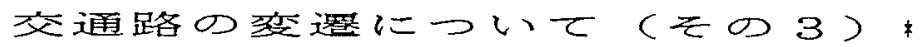

一南北幹線加東西連絡道路の整備へ一

A Historical Study of the Transportation on Kisoji in Nagano Prefecture

西 漳 二**

By Junji NISHI

\begin{abstract}
Nakasen-Dou-Kisoji was gone on equipping for a trunk line to national land formation in stead of Tosan road.

With the changes of the means of transportation (people $\rightarrow$ oxen and horses $\rightarrow$ railway and national road $\rightarrow$ expressway and Shinkansen), the route was obliged to alter.

In Edo period, four connection roads which $l$ inked $K$ iso road(Kiso valley) with Tosan road(Ina valley) of a north-south principal road, it were improved as a road which oxen and horses were able to pass, and a network of roads was established. And it promoted an exchange of goods and people between Kiso and Ina area. These four roads crossed Gonbei, Usikubi, Seinaiji, and Oodaira pass from the north.

This paper describes about the process of building up Gonbei pass road.
\end{abstract}

信州中山道木兽路は、国土形成を担う官道として、 東山道に替るものとして整萑が進めら机てきた ${ }^{1}$ 。 そして、交通具においても、人 $\rightarrow$ 牛馬 $\rightarrow$ 鉄道（国道） $\rightarrow$ 高速道路 (新幹線) と変化する中で、具体のルー トは、それなりの変更を余儀無くされてきたことも 事実であろう。

本報告は、中山道木曽路という南北幹線に加えて、 東西方向の連絡路として、権兵衛街道の成立に至る 状況について記述するものである。

\section{1. 島居峠}

“日本の屋根”長野県からは太平洋に天竜川と木 曽川、日本海には信漂川と姫川が流れ出している。 木曾の鳥居蛙は木曾川と姩川との分水頜となってい る。昔から人や文化は川にそって往来し、虾をこえ てまわりの地域と結ばれていた。

木兽は南は木曾川を通じて東海地方、さらに西日 本にとつながり、西は王滰から裏木兽、開田や境跕

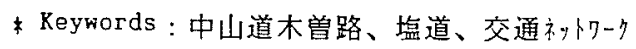
**正会員 工博 バンフィクコンサルタンツ(侏総合研究所 （テ206 東京都多摩市関戸1-7-5）
から飛騨地方に通じてさらに北陸地方とも結ばれて いる。北は島居㿟から松本平に、東は木曾山脈の両 端の站—神坂蹗、権兵衛䟔などから円那谷と結ば れ、各地域の文化が見られる2゙。

木曽川は鉢盛山に発して遠く伊勢鹊に注いでいる。 最上流部の木祖村は意外と広々としていて、段丘地 形が発達している。この段芹上に緡文・平安時代の 遗跡が分布する ${ }^{31}$ 。その一つ、木曾郡日義村宦ノ越 の日義小・中学校付近、標高 $880 \mathrm{~m}$ 段丘より発掘さ れた「お等の森道跡」からは、縄文時代中期後半住 居址 3 、平安時代後半住居址 24 軒ほかが検出されて いるい。

中世においても、木曽川を利用して運搬される木 兽材 (南禅寺の造営ほか) や木曾駒の産地として菲 園よいう形で都との関係が保たれていた

そして、木曽が正史の上に姿を現わすのは 8 世紀 の初頭である。すなわち「続日本紀』大宝 2 年 12 月 壬寅（10日）の条に「始開美濃国岐蘇山道」と見え るのがそれである。この 702 (大宝 2) 年の記事が 史籍の上での木曾の「夜明け」に当たるが、それか ら11年を経た同畫の和銅 6 年 7 月 7 日の条には「秋 7 月戊辰、美濃 - 信濃二国之堺、径道険隘、往襄蔓 
難、仍通吉知路」とある ${ }^{6)}$ 。

和銅の「吉蘇路」は、美濃と信濃の国付を結ぶ最 短距離であって、しかも神坂越えのような瞼難路で はなかったにもかかわらず、延喜の「官道」がこの 道を避け、再び神坂越えの山道を選ぶようになった のは、その当時の木畺谷は、「吉蘇・小吉蘇の两村」 があるだけと指摘されるような山間僻地であったた めに、駅魀上の便が悪かったこと、つまり、官道之 しての機能を果す上の継送条件を欠いていたことに 原因があったといわれている7。

官道の選に入らなかったとはいえ、吉蘇路は廃道 に慢したわけではなく、日程の短縮を望む旅行者や、 信濃から上進する貢馬など貢物の輸送などには、吉 蘇路が多く利用さ机た（その後、良質材こしての木 曾材 ${ }^{3)}$ は、江戸へも中山道木兽路を経て流通した）。 時間を経て現在、中央西線に乗車すると「田毎の 月」の姨捨山上、木兽川の「寝覚の床」上之もに、 車空説明されるものに「鳥居トンネル」がある。

この站が有名なのは、太平洋側と日本海側とを二 分する単なる分水嶺ではないことである。信浱川ー 屝川の支流である系良井川と、木曾川の最上流とが、

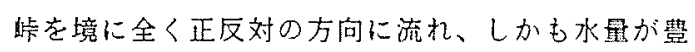
かで、污れを知らない清流が、視覚に訴えるに十分 な要素をもっているからである9?。

713 (和銅 6) 年弈蘇路が開通していらい、1250 年以上の歳月を経ているが、この間、鳥居䟔を含め て信州は、自然的・地理的・人文的に、日本の中央 部を、継続して制してきたよいえる。

\section{2.中山道のルート設定}

1600 (慶長 5) 年、関ヶ原の戦いで腾利をおさ方 た徳川氏は、翌年、まず東海道に伝烈の制を設け、 次いで1602(慶長7) 年、中山道にも伝馬の制度を 設けた。

こうして、再び、中央集権的国家の管理する駅制 に近い機能と軍事障壁の機能を併せもった幹線道路 整湖が着手された。

東山道の信亚路におけるルートは、当初、京から 美濃、御坂峠、伊那、杖笑峠、諏訪、雨境虲、佐久 入山峠 (碓水) に通じていたが、平安時代に入り、 信謴国府が上田から松本に移ったことにより、松本、 保福寺虾、上田、碓办跕回りに变更され、何世紀も

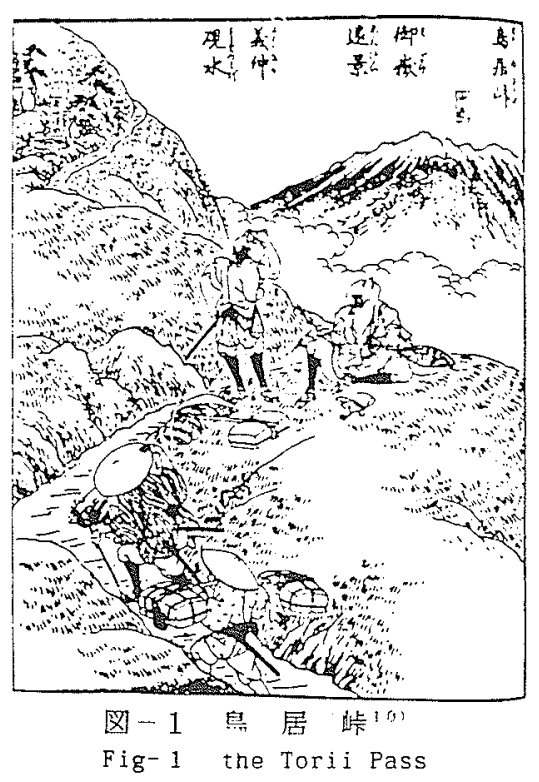

の間使わ机ていた。

1602（慶長 7 ）年の徳川氏による中山道の制定に より、母体であった東山道のうち、信濃路の諏訪湖 付近ルートは再び变更された。すな机ち、伊那、杖 突祡、諏訪を経て、武田信玄が軍用道路（棒道己い 引れる）としても使った大門虲を越え、佐久入山虾 に抜けるルートから下諏訪、和田蛙、和田、長窪、 芦田回りのルートに変わったのである。

この路線への变更は「2〜3里毎に必ず宿駅を置 き、宿駅は戦国時代以来の城下町、小領主の館など、 㽣成集落を極力活用する方針でルートを設定した」 ためであるといわれている。当時の宿駅設定は、徒 歩、翼蘢、馬などを前提として、そ机らの生理的な 一日の行動圈の制約、既成集落の活用を基碟とした。 一方、駅間距離よりも地勢に主眼をおいて対间的に 設けられる特殊な場台もあった。例えば、川の雨岸、

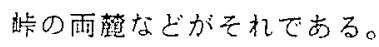

このような街道ルートと宿の設定策は、徳川政権 の早期安定を図る趣旨から、少ない投凅で即效性が 発揮できる例面はもちろん、こ机らが歴史的にみて 要害の地であることからもわかるとおり、軍事的要 請にもかなうものであっだ”。

\section{3. 塩道としての中山道木兽路}

信州長野地力は、日本の屋根上呼ば机、中央部に 急峻な山岳が重思し、南北幅も最大であるだけに、 


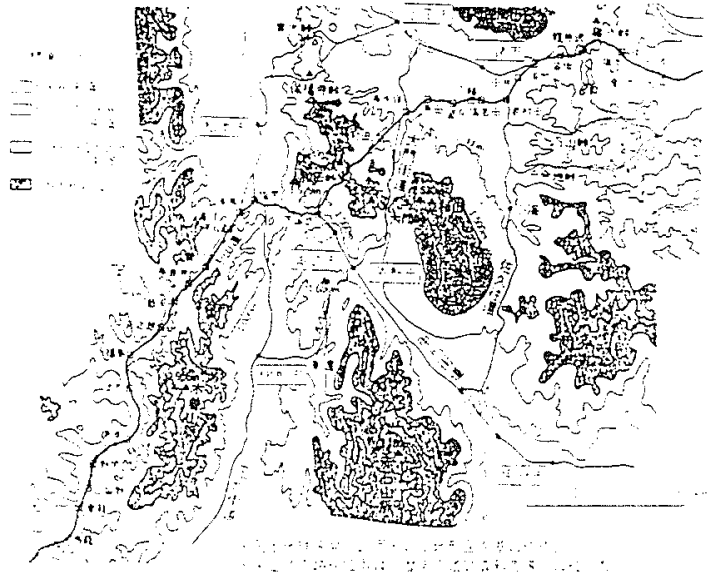

园-2 中山道ルート地勢図 ${ }^{12}$

Fig-2 Route Map of Nakasendou

内陸・臨海雨地域を結ぶ交通は、地域経済の維持の 上から重要な位置を占め、早くから発達した。上く に、近世に入り日本国内の流通経済の進展により一 層促進された。

生活上欠かせない壏、米の流通は、中でも最重要 品目であった。

中津から木曾谷に向かう塩の移送路は中山道に上 ったが、そのコースは山道で落台・馬籠・站・馬籠

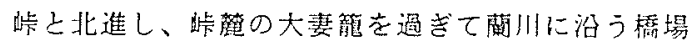
・妻籠を通り、木曾川左岸を三留野・野尻・須原・ 上松上結び、南木曾谷の中心の木曾福島に達した。 福島からさらに木曾谷を北上して、宫越を経て鳥居 峠南葓の薮原に至るものである。谷道を利用した比 皎的平坦な移送路であっだろ。

福島は、「此宿八木兽中之时中にて諸商人多く諸 物資交易いたし身柄頭分有福之者も有之第一女塄 上近在村々百姓へ預ヶ䈯駒取上每年馬市を立其外系

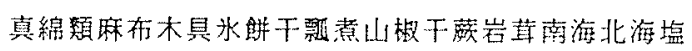

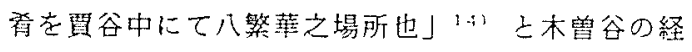
済中心地であった。しかも、塩魚をはじめ一般の南 海・北海雨物資が交錯しているところから、南・北 雨塩がともに搬入されたことが容易に想像される。

福島以北では、宮越・短原が主要な中継地さなっ た。前者は、天保 9 年 (1838) には贯商家262軒、 口数1.152人、後者は、農家126軒、口数494人の 宿場町であった。また、木曾川之奈良井川（信溜川 支流）の分水界をなす鳥居峠の南视集落をなす數原
は、木兽谷の北限集落さして経済的に重要な位置に おかれた。

木畺谷への程の移入は、主上して木曽の中牛によ る今渡・中津・名古屋方面からの移入塩之中馬によ る松本・塩尻方面からの搬入があり、南・北・東の 三塩が複合した。木曾谷へ移入さ机たこ机らの埗は、 市が開かれて経戌の中心地之なった木畺福島をはじ め、牛方の中継問屋や塩店の置かれた數原・田の上 ・馬籠・宮越その他から山間諎村へ転売されていっ た。交通機闺は、牛背之ともに「持子」々いう人背 移送が利用さ机だ。
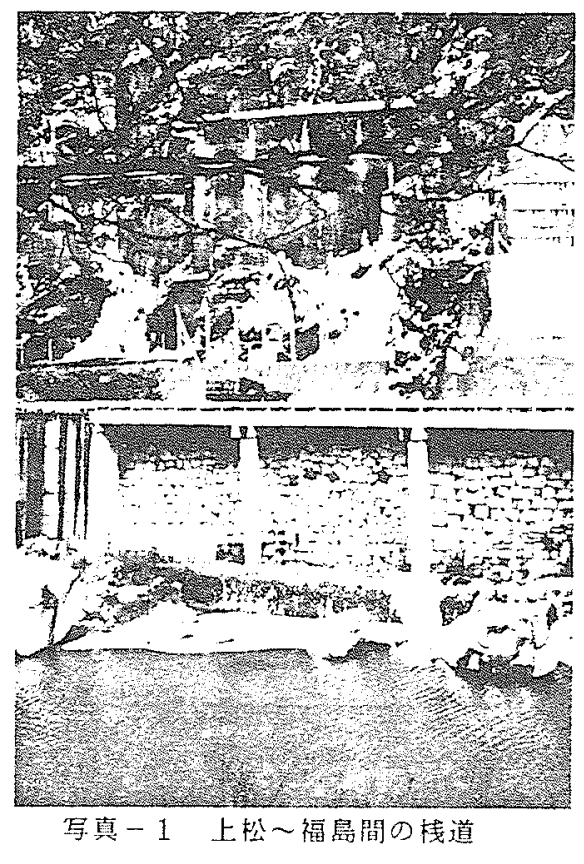

Photo- 1 Plank Road in Kiso

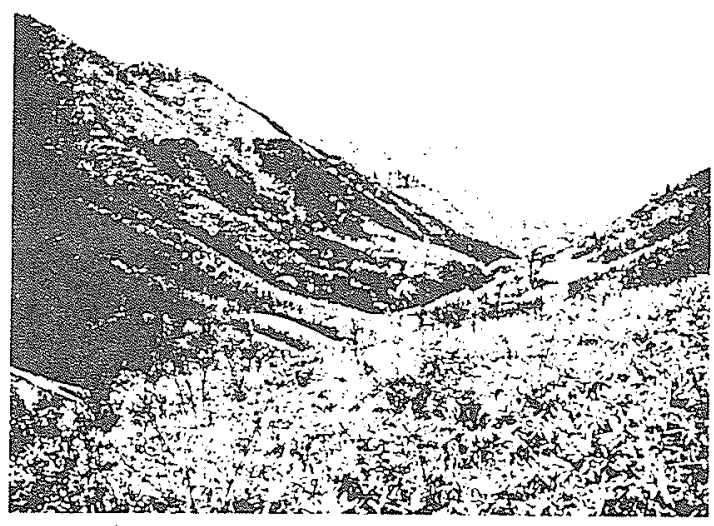

写真一2 権兵衛㑐頂上より木曾を望む

Photo- 2 View from the Gonbei Pass 


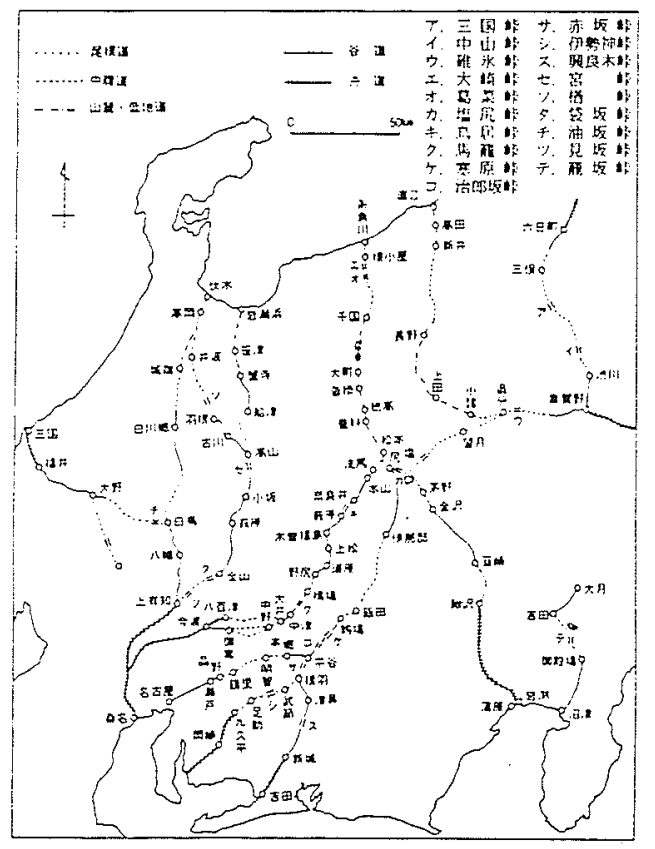

図-3 中部地方の地形位置から分類した 塩道 (近世) ${ }^{163}$

Fig- 3 Type Classification of Salt Roads

\section{4. 東西交通路としての権兵衛街道}

木曾での経済交流は、以上にみた南北交通を幹線 路としたが、それを培落する東西交通も看過できな い。東西方向の交通路には、木曾山脈を横断して伊 那谷と連結した権兵衛街道や大平街道、飛騨高山之 結んだ野麦街道などがあげられる。権兵衛街道は 1696 (元禄 9) 年に開削され、北部の木兽・伊那雨 谷を結ぶ連絡路として重要であった。とくに、伊那 からの御蔵米や売米の移送が多かった。古老談によ れば、その交通日程は、伊那を早朝出発し、神谷の 問屋へ 2 時ごろ到着し、夜半䚄く伊那に㥜着する行

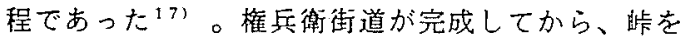
こえて木兽へ移出した米の量は、表一1に示すとお りである。

しかし、野麦街道と権兵衛街道は、ともに高山盆 地・木曾谷・伊那盆地を連絡する主要な横断路であ ったにもかかわらず、塩の移入に関する記载がない のはどうしてであろうか。

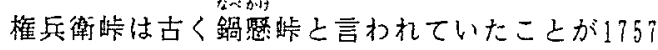
（宝曆 7) 年の『吉䧰志略】にあり、険難要害の地 であることが記されている。
表一1 権兵衛站越しに木曾へ移出した米の星 Table-1 Amount of Rice through the Gonbei Pass

\begin{tabular}{|c|c|c|c|}
\hline 年 代 (西智) & 移讪䓡数 & 送 & 先 \\
\hline 元渌10 (159i) & 423 & 钟公矱兵㭪 & \\
\hline 宝永 6 (1709) & 845 & 抽谷 & \\
\hline 胃保1（1741） & 455 & 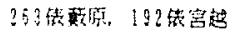 & \\
\hline 文政7 (1824) & $\begin{array}{r}2494 \\
333\end{array}$ & 插谷 & \\
\hline 文政 8 (1825) & $212 !$ & & \\
\hline 文政 9（1826） & $\begin{array}{r}370 \\
1987\end{array}$ & & \\
\hline 文政11（1828） & $\begin{array}{r}1987 \\
916\end{array}$ & 神谷 & \\
\hline 文政12 (1829) & $\begin{array}{r}1129 \\
899 \\
15 !\end{array}$ & 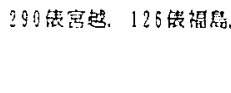 & 汭整神谷 \\
\hline 文政13 (1830) & 1231 & 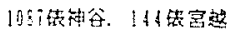 & \\
\hline 天保 2 (183!) & $\begin{array}{r}540 \\
10\end{array}$ & 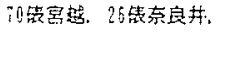 & 454 镂神谷 \\
\hline 天保 3（1832） & $28:$ & 钤谷 & \\
\hline 天保 4 (1833) & 259 & 199 俵神谷，60传宮超 & \\
\hline 天保 6 (1835) & 863 & 种谷 & \\
\hline
\end{tabular}

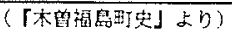

開道のいきさつについて、「上伊那誌』歴史編に は「権兵衛站の開警はおそらく彼の発意であろうと 思われる。すなわち権兵衛は支配者の山村家に請い、 木曽11宿の賛成を得 1695 (元禄 8) 年莽低に出願し て許可を得ようとしたが、まず地元伊那側の同意を 得ることを要するということで、翌 9 年福島町の年 寄永井三右衛門、宮越の斉藤治右衛門の雨他表者に 権兵衛も同行し、筫輪領の木下村割元名主治郎四郎 方へ来て、此の道が切開かれれば、米款不目由の木 兽谷故、当郡から買求如付送ることができ双方勝手 が宣教しいことと思うから何卒御得心下されたいと 申入れた。そこで、治郎四郎は箕翰領各村の名主を 参集させて拹議し、咅議承認に傾いたが、この時、 大出村名主藤右衛門が、この道が切開かれれば木兽 宿への助楖が課せられる恐れがあるこ上を指摘した。 この結果、木畺側に対し、道中奉行に願って筫翰領 の村々からは助馬 1 匹も呼ばないこと、万一、助馬 を叫付けられたらば、その助馬の代りを木兽中で勤 めるこの確約を要求し、次の一札を取って得心した。 」とあり、箕翰町木下の萩原太郎氏蔵の「一札之事」 を揭げてあるが、その一札（元禄九年子之二月）に は「今度木兽之谷拾壱ヶ宿二て、宮腰村より其元江 直ク二越候歩行路馬足之自由二通ひ候様致候へ八木 兽中勝手二罷成候二付」上書き出され、助制につい ては「右之通御相対之上八御道中御奉行神尾潢前守 様江弥道筋御詐訴可仕候、我等共願之通相吁申二お ひては、助馬之義被仰付候共 右申合候通り壳匹も 
㭔申間数候事」とあり、さらに、万ーにも助馬を仰 せっけられたとしても、其の代り馬を増測で勤め る上、その為の御詮議があったとしても、だこまで も出向いて決して蓟迷惑はかけない事、また此の申 合せは、たとえどの様に御任㯰替りがあ万うと、道 中奉行が替っても、古証文の年数切れだと言われて も、後々永々に相違まじき事、というもので、その 証文の固さには後に道中奉行が憋いたという念の入 ったものである。しかし、1695(元䘵8) 年11月、 木曾川宿問星が連名で幕府に出した文聙には木曽御 伝馬宿11宿とも小村であるにもかかわらず驻還の他 の富裕な宿場同様に勤力てきたが近年は山も繁昌せ ず商人の荷物も伊那街道を通ってしまい困筙をして いるので御求金を願い度い之し、又、今後は道程 $5 、$ 6里までの村へ助㳰を仰付けて欲しいと願い、宮越 宿から伊那への道は宮越から小沢まで5里であり今 までは歩行道であったが牛馬が通行出来るように道 を造り立てることを許可してほしいというもので、

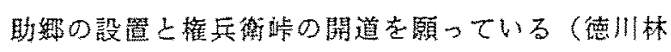
政史研究所所蔵文書、「長野県史】) ので、木曾側 の開道計画には単に米教移入の事げけではなく、併 せて、助㽎設置の底意も強かったと思的れる。

一方、高遠領の村々では開道に対して反対で、 ア上伊那誌』によれば「木曾側の要鿁に対して名主 の協議の結果、平沢村名主八郎右衛門は相役の長三

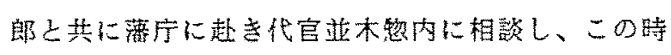
地元の意向上して開道後の道作りに村人が難倿をす る、今まで背負荷渡世の者が生活に困筙する、の 2 点から反対である旨を告げ、高遠蓶でもをの時を汲 んで消極的であった」としている。

しかし、開道についての木曾啷の熱意は固く、箕 翰領では領主板倉氏の諒解を得て程極な協力態勢で あったので、高遠領を通らず筫㫻領内に道をあける ことに決めて工事をすすめた。結局、最終的には高 遠領側も替成せざる在得ない状況となって合意し、 1696 (元禄9)年 6 月に工事は終了した ${ }^{199} 。$

時を経て1975（昭和50）年に、伊那市、木曾福島 町・高山市を結ぶ国道361号線が決められた。国道 の羽㴊・神谷間は、まだ車道としては開通していな いが、姥神㫮の下にトンネルをあけて通す計画であ $ろ^{20)}$ 。

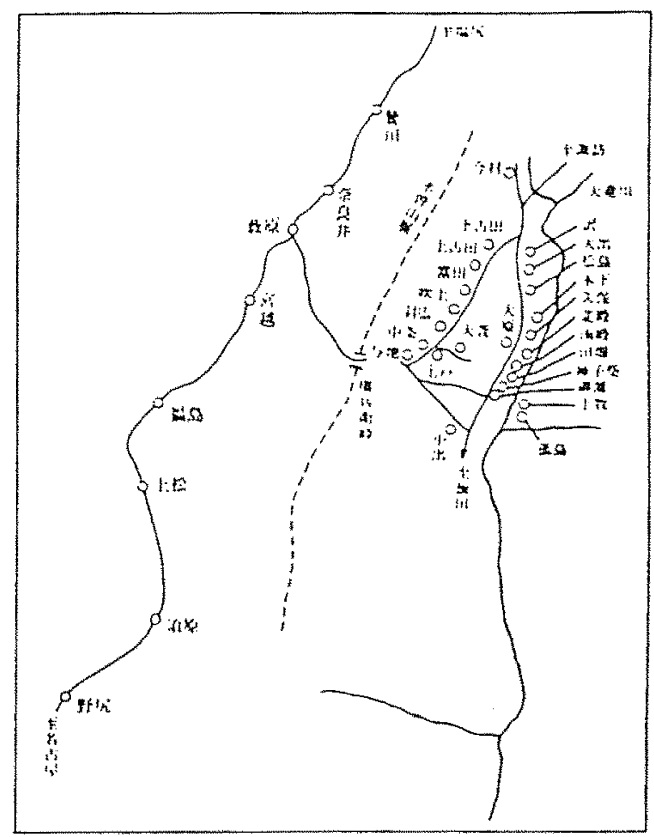

目一-4中三宿助班植圆 ${ }^{19}$

Fig- 4 Location of the Sukegou Village connected to the Gonbei Pass

\section{5. 結びに代えて}

陸上交通路展開の阻害要因の第1は、自然的地形

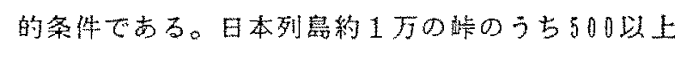
が信州に位置しているといわ礼る蝬険な地勢的条件 の中で、物流を担うための道路拡蝠（最初は、人力 から牛馬の通行を目標に)が僬められてきた。

第2 は、木曾本流の右岸・左岸を通行するにして も、その支流には、河川を渡る施殿（橋、渡船）の 整備が必要となる。東海道之中山道之がよく対比さ れるゅえんともなっている。

第 3 は、最も重要なことであるが、そ扎はソフト 面の条件整備である。たとえ、物理的なもノとして の道路絧が敷設されたとしても、そ机を支える「宿 場」こいうソフト機能の閶題である゙”。

しかし、信州の百姓が䍔閣余業的に行っていた馬 稼ぎに端を発した「中馬」が、寛永時代には江戸・ 酸河・相模にまで活動の䡉用を㕕げていった22 (いわば現代の宅祀便）ように、このソフトのシス テムは相当「柔」な構造にしておく必要があるう。 いずれにせ上、市・民・官・学が良い意味での政 治の場に势活し、智恵を出し合っていく中で、「政 
策」の形成システムゔくりが、今、改めて欲求され ている。

このような視点から権兵衛街道をプロモートした 宮越村神谷在の古㚼権兵衛をみるとき、そこに、土 木のもつ社会的役割の一端を垣間見ることができる のではなかろうか。同時に、名を残すことなく、営 々と働いてきた多くの先達の上に、今日の日本の国 土が形成されてきたことは言うまでもない。

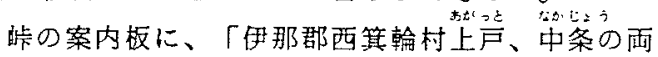
部落民が木曾谷からの引水を思いつき……」」と記 されているように、後日、権兵衛挊を経て用水路の 建設が行なわれた。木曾側が米を熱望していたと同 じように、伊那側、特に西箕輸では水田用水が不足 していた。

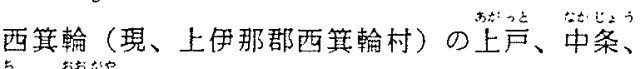
与地、大宣の 4 ヶ村が、水田用水を権兵衛峠の向う 側を流れる奈良井川の上流白川に求めたという、長 期間にわたる水利権抗争運動にも、「塩」に加えて 「水」に対する人間の生命愿への限りない希求を感 ずる次第である。

\section{参考文献・註}

1) 西 淳二：交通路の变遷について（その2）、 土木史研究第14号、P331、1994.6

2) 生駒勘七・神村透・小松芳郎：図説・木曾の 歴史、P18、郷土出版社、1982.2

3）長野県考古学会：遗跡之遭物、P17、信浿每日 新闋社、1982.3

4) 長野県教育委員会文化課：長野県埋藏文化財発 掘調查要覧その3、P340、1979.7

5) 小林計一郎：信濃中世史考、P294 295、吉川 弘文館、1982.5

6) 所三男編：近世林業史の研究、P499、吉川弘 文館、1980.2

7) 全上5)、P502 504

8）木曾川は運材河川として開発され、秀吉の時代 から家康・義直時代へと降るにつれてますます影 著となる。これが木曾川舟運の発達をいちじるし く阻害した。近世になってからの木兽川は「連材 が一般の通船に優先する」を建前乞したため、冬 から春にかけての運材期間中の舟航は杜絶状態に 陥るのを常とした。とくに慶長末から寛永年間に
およんだ湃採期の運材は年間を通じて行なわれる ことが多かったので、岐皁・加納・笠菘辺之飛駢 方面上を上り下りする荷物は船を避けて飛戦街道 を、一方の名古屋と東濃・木兽筋之の間の商品荷 物は、小牧街道から中山道を駄送することを余儀 なくされ、それが陸上運翰之継荷問屋の発達を助 長するのである。そのような荷動きの重心が木曾 川の船に移るのは、城下町の造営がほぼ一段落し、 それまでの爆発的な木材採運活動が大方平静を保 つようになる延宝以降のことである。（豊田 武 ・児玉幸多：交通史、体系日本史叢曺24、P367 368 、山川出版社、1970.12)

9）市川健夫：信州の虾、P214、第一法規出版、 1972.12

10）川绮 敏：木曾一歴史・文学・地誌一、 P98、木耳社、1973.10

11) 長井典雄：中山道和田宿の記録、P5 6、山海 堂、 1990.6

12) 全上11)、P4

13) 富岡儀八: 日本の塩道、P316、1978

14) 脇田雅彦: 木曾巡行記、P2 2 23、一宮史談会、 1973、福鼠宿は、宿内に農商家313軒、口数 1.022人、宿外上之段町に農商家 111 軒、只数 302 人、同向町に農商家48軘、擞186人、同八 澤町に職人家82軒、可数 198 人、（天保 9 年）

15) 全上13)、P316 320

16) 全上 13$) 、 P 67$

17) 全上 (13)、P319

18）伊那市教育委員会：権兵衛街道、P1 5 、 1985.?

19）長野県文化盰保護協会：中山道信溳二六宿、 P370、信湏每日新聞社、1980.11

20)野村和正：峘の道路史、P236、山海堂、1994.3

21) 西涼二・㷊田 箱根路の变遈について、 土木史研究№.13、P531、1993.6

22) 大石進：日本技術の社会史、P181、第 8 巻、 交通運翰、1985 